CENTRE FOR COMPARATIVE ECONOMICS
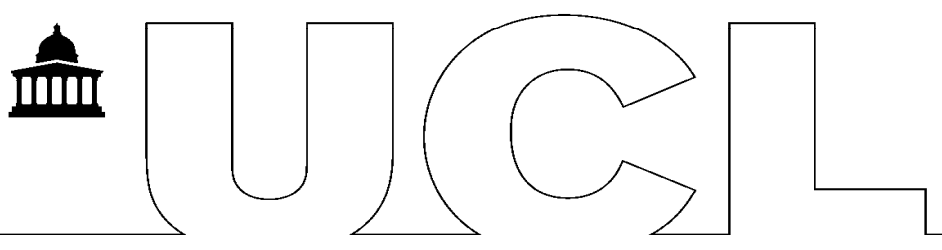

\author{
UCL SSEES \\ Centre for Comparative Economics
}

ARE SYSTEMS OF INNOVATION IN EASTERN EUROPE EFFICIENT?

Victoria Kravtsovaa and Slavo Radosevic ${ }^{b}$

${ }^{a}$ University of Glasgow, email: v.kravtsova@lbss.gla.ac.uk

${ }^{b}$ University College London, email: s.radosevic@ssees.ucl.ac.uk

Economics Working Paper No.101

November 2009

Centre for Comparative Economics UCL School of Slavonic and East European Studies

Gower Street, London, WC1E 6BT

Tel: $+44(0) 2076798519$

Fax: $+44(0) 2076798777$

Email: cce@ssees.ucl.ac.uk

\footnotetext{
${ }^{1}$ The research that forms the basis for this paper was funded in part by the EU Framework Programme V project: 'EU Integration and the Prospects for Catch-Up Development in EECs: the Determinants of the Productivity Gap' Contract No HPSE-CT2001-00065.
} 


\title{
ARE SYSTEMS OF INNOVATION IN EASTERN EUROPE EFFICIENT? ${ }^{1}$
}

\author{
Victoria Kravtsova \\ University of Glasgow \\ v.kravtsova@lbss.gla.ac.uk \\ Slavo Radosevic \\ University College London \\ s.radosevic@ssees.ucl.ac.uk
}

\begin{abstract}
This paper explores the determinants of the productivity in the countries of Eastern Europe (EE) through the perspective of 'narrow' and 'broad' national systems of innovation (NSI). Based on panel econometrics it examines the extent to which systems in EE could be considered '(in)efficient'. Our results suggest that the EE countries have lower levels of productivity than might be expected given their research and development (R\&D), innovation and production capabilities. The inefficiencies of 'broad' NSI are compounded by the inefficiencies of 'narrow' NSI in terms of generating numbers of science and technology publications and resident patents relative to R\&D employment, compared to the rest of the world. Our results point to an important distinction between technology and production capability as the drivers of productivity improvements, and provide some policy implications.
\end{abstract}

1 The research that forms the basis for this paper was funded in part by the EU Framework Programme V project: 'EU Integration and the Prospects for Catch-Up Development in EECs: the Determinants of the Productivity Gap' Contract No HPSE-CT2001-00065. 


\section{INTRODUCTION}

The type of growth experienced by the countries of Eastern Europe (EE) after 1989 seems to have been a spurt rather than progressive catch-up, and the 2007-2009 global financial crisis in particular has demonstrated the fragility of this growth. At the same time, there are several growth accounting exercises that suggest that growth in this region during the late 1990 s and early 2000 s was based mainly on total factor productivity (TFP), which from a conventional economic perspective suggests that this growth should be sustainable since it is based on technical change. For example, a World Bank study (see Alam et al., 2008) on productivity in EE demonstrates that it is largely attributable to TFP. However, a high TFP share does not necessarily reflect investment in R\&D and innovation, which makes the sustainability of this growth questionable. We argue here that productivity growth in the region is based mainly on production, not innovation capability. Whether this production capability can be converted into greater productivity as well as S\&T outputs depends largely on the efficiency of the national systems of innovation (NSI). So, in institutional terms, the long-term growth of EE countries will depend on whether their 'broad' and 'narrow' NSI can become efficient and effective carriers of innovation based growth.

We explore the technological determinants of productivity (research and development - R\&D, and innovation and production capability) in EE through from a system of innovation perspective. We present a quantitative analysis which by definition means that we abstract from qualitative issues including the institutional complexity of this mega-region. In conceptual terms, we distinguish between 'narrow' and 'broad' NSI based on the distinction introduced by Lundvall (1992) and Freeman (1987, 2006), which has become accepted in the systems of innovation literature (see Edquist, 1997). This concept stems from the understanding that technical change is inextricably linked to the overall institutional fabric of society rather than only to the narrowly defined R\&D/S\&T 
(science and technology) system. A narrow NSI embraces those institutions that are directly and explicitly involved in R\&D and the dissemination of its results. In the broad sense the NSI embraces the social, economic and political contexts of technical and organizational innovation (Freeman, 1987 2006). Thus, we distinguish between the inefficiencies of narrow and broad innovation systems. The inefficiencies of the former lie in the process of conversion from $\mathrm{R} \& \mathrm{D} /$ innovation inputs into $\mathrm{R} \& \mathrm{D} /$ innovation outputs. The inefficiencies of broad NSI lie in the process of conversion of production and technology inputs into productivity.

The issue of 'inefficiencies' in NSI is quite controversial (see Niosi, 2002) and especially so in the case of EE where increases in productivity and high share of TFP during the 1990s and early 2000s have been accompanied by declines in R\&D, which suggests that productivity increases have been generated by non-R\&D factors. Naturally, there is a plethora of non-production (cf. institutional and cultural) factors that affect productivity, but we are interested in the impact of production and technology capabilities (R\&D and innovation) on productivity in these economies.

The distinction between production and technology (R\&D and innovation) capabilities is important for understanding technical change in developing countries. The bulk of the technical change activities in these economies is related to improvements to production capability rather than R\&D and innovation (see e.g. Westphal, Ross_Larson and Dahlman, 1987; Lall, 1990; Evenson and Westphal, 1995; Bell, 1997; Katz, 1987; Dutrenit, 2000; Pavitt and Bell, 1993). Because EE countries are catching-up economies this distinction for them is highly relevant.

Unlike R\&D and innovation capabilities which are 'captured' in the OECD Frascati and Oslo statistical manuals, production capability belongs to the realm of qualitative and case study research. In this paper we use ISO9000 certification data as a macro-proxy for production capability and $\mathrm{R} \& \mathrm{D}$, and patents as a proxy for 
technological capability. Our analysis is based on the sample of 154 developed, developing and EE countries. ${ }^{2}$

The main conclusion from our study is that EE countries have lower levels of productivity than might be expected given their $R \& D$ and production capabilities, and lower level of S\&T outputs (papers and patents) given the numbers of their researchers. Hence, there are inefficiencies in both the 'narrow' and 'broad' NSI. In view of their growth, which so far has been based predominantly on production rather than technological capability, we conclude that policy in EE should be distinguish better between technology generation and technology use, i.e. absorptive capability.

In Section 2 we introduce the issues of productivity and R\&D in EE, drawing on broader evidence and elaborating on the notions of production and technology (innovation and $R \& D$ ) capability, which are necessary to interpret the data on $R \& D$, patents and ISO900 certification. We test whether the sizes of the R\&D systems in EE countries correspond to their income levels, given the inherited 'oversized' socialist system. In Sections 3 and 4 respectively, we explore the issues of broad NSI and narrow NSI efficiencies in EE. Section 5 summarizes some key conclusions and discusses the policy implications of our findings.

\section{PRODUCTIVITY AND TECHNICAL CHANGE IN EASTERN EUROPE: INTRODUCTION AND CONCEPTUAL FRAMEWORK}

\footnotetext{
${ }^{2}$ EE countries include all the so called transition economies i.e. the countries of central, eastern and south-eastern Europe including the CIS countries. We exclude from the OECD countries belonging to EE. The notion of EE includes central Asian countries, which geographically may be incorrect, but has come to be accepted in the political economy literature based on their common socialist legacy. We do not use the term transition economies, which we consider has lost its relevance.
} 
In the transition period, growth in EE was based mainly on removing distortions and introducing macro - and micro-organizational innovations (see Havrylyshyn et al., 1998; Havrylyshyn, 2008; Berg et al., 1999; Christofferson and Doyle, 1998; Mickiewicz, 2005; Chakravarti et al., 2005). In this period, reallocations and restructuring were more important for growth than factor accumulation, for example, aggregate investment ratios had no explanatory power. Efficiency gains appear to be the main, if not the sole, source of growth in EE (Zukowski, 1998). Extensive econometric work undertaken by World Bank, EBRD and IMF staff shows that the major factors explaining recovery and growth in $\mathrm{EE}$ are the initial conditions, macroeconomic policies, and structural reforms (e.g. see Havrylyshyn, 2001; Fischer et al., 1998; Berg et al., 1999; Falcetti et al., 2006).

In the long term, growth in EE will depend increasingly on the expansion of physical and human capital, and especially on technology accumulation. Crafts and Kaiser (2004) show that during the 1990s, in three out of five central European economies, the contribution of TFP was relatively high at $2.3-2.4 \% .^{3}$ In relative terms, TFP in four out of five central European countries has contributed to a GDP growth from 55\% to $121 \%{ }^{4}$.

A World Bank study conducted by Alam et al. (2008) demonstrates that TFP growth accounted for over $80 \%$ of total output growth in EE in 1999-2005, which is much higher than other world regions. These estimates may be exaggerated as a result of higher capacity utilization as growth rebounded after the sharp contractions during the

\footnotetext{
${ }^{3}$ However, for 1991-(95)97 Campos and Corricelli (2002) show that the contribution of TFP to growth was negative in four (Slovakia, Czech R, Croatia and Bulgaria) and positive in three EE economies (Hungary, Poland and Slovenia). These differences in TFP are partly due to the different periods considered, which extend to 1995(1997) and 1999 respectively, and partly to different assumptions about shares of labour and capital. Campos and Corricelli (2002) assume labour and capital shares to be 0.7 and 0.3 respectively. while Crafts and Kaiser (2004) assume shares of 0.65 and 0.35 . Higher share of labour in conditions of radical reduction possibly exaggerate the weight of TFP, which in conditions of overall output decline produce strong declines in TFP. However, these differences are too small to explain the huge variation in the contributions of different components to GDP, which suggests caution in making generalizations based on growth accounting exercises.

${ }^{4}$ The literature suggests that on average TFP contributes to half of cross country differences in per capita income (Lederman and Maloney, 2003), which makes the contribution of TFP to growth in EE quite substantial.
} 
early years of transition. However, estimates for some countries (cf. Russia) where it is possible to adjust for capacity utilization, shows that even after adjusting TFP gains for employed resources, TFP shares still account for nearly two-thirds of overall growth during 1999-2005 (Alam et al., 2008, p. 75).

The literature on the determinants of productivity suggests several related reasons for productivity growth: increased capital intensity; human capital; technological change; and competition (OECD, 2001). The key problem in trying to explore the determinants of productivity growth is whether it is appropriate to consider each individual component as a separate factor, since their contributions are closely interrelated (OECD, 2001). One of the most important drivers of technological change is R\&D. Hence, as is the case with other factors, the issue is whether it is appropriate to isolate $\mathrm{R} \& \mathrm{D}$ as a driver of productivity growth, from other factors. Aggregate studies often find that $R \& D$ provides a positive contribution to productivity growth. For example, Verspagen (2001) finds that in the last 10 to 20 years $\mathrm{R} \& \mathrm{D}$ has become a crucial part of catch up strategies, that is, R\&D is no longer associated only with the global technology frontier. Another reason is that differences among countries in terms of 'pure' technological competitiveness (patents) are becoming more and more important for explaining differences in growth. At the aggregate level, $R \& D$ expenditure tends to show a statistically significant relationship to productivity growth, but explains only a relatively small part of overall annual movements in multi-factor productivity, which points to the influence of other factors (OECD, 2001, p. 113).

As pointed out in EC (2002), R\&D supply is only a part of the overall process of innovation that ends with a finished product placed in the market or to national economic growth. The degree of technology and knowledge flows across public and private sectors strongly affects the impact of technology on the economy (OECD, 2002). So, if we want to understand the effects of R\&D and innovation on productivity we must 
look beyond the R\&D sector. Since EE countries are catching up economies their growth depends on both R\&D and on production and innovation capability. And, in addition, the relationship between $\mathrm{R} \& \mathrm{D}$, innovation and productivity has been changing in the EE region.

The socialist period was specific in terms of technology (R\&D and innovation) accumulation not leading to increased TFP. In the post-socialist period, however, we have seen a tendency towards increased TFP but declining R\&D. Hence, EE seems to be an interesting case which illustrates that technological change does not automatically follow from increases in productivity, and vice versa.

The stagnation of EE since the mid-1970s was driven by ineffective investments in capital goods and technology such that extensive investments in capital inputs were accompanied by slow TFP growth (van Ark, 1999). In the early transition period, TFP deteriorated, but by the end of the 1990s the overall contribution of TFP was significantly positive, and productivity growth was being driven mainly by the shedding of labour (Van Ark, 1999). Van Ark and Piatkowski (2004) show that reductions in labour inputs made substantial contributions to labour productivity during the 1990s: inefficient firms exited or laid off labour, which enabled the remaining firms to restructure. This led to much larger declines in per capita GDP than in labour productivity. Van Ark and Piatkowski (2004, p. 5) calculate that only $20 \%$ of the relatively strong productivity convergence between the 10 new EU member states from the EE, and the 'old' EU-15, has been driven by faster output growth in the EE countries, while $80 \%$ is due to job cuts. This poses the question of what will be the sources of further productivity growth as productivity - driven mainly by labour savings -exhausts its potential.

There are many different drivers of productivity and we do not try to account for them all. We explore the role of technological capability composed of R\&D and 
innovation capabilities (proxied by patents) and of production capability (proxied by ISO9000 certification) to explain levels of productivity. In the EE catching up countries, growth is based much more on the use of foreign technology than on own technology development. Technology use capabilities are composed of basic operating skills and capabilities and technician and craft skills and capabilities, while technology development is based on R\&D, design, and engineering (see Arnold et al., 2000). Hence, it is important to distinguish between the capabilities for developing (R\&D and patenting) and using (production) technology. R\&D and patents are proxies respectively for the capabilities for developing technology developing or generating change. We use ISO9000 certification as a proxy of technology using or production capabilities. These are the capabilities required to produce efficiently (on a level with best practice) using the existing equipment. There is a lack of research on the relationship between production capability and innovation (see Abrunhosa and Moura E Sa, 2008 and Lypez Mielgo et al., 2009a,b, which are rare exceptions).

We assume that the dominant focus of EE enterprises on mastering production capability explains why growth is not automatically accompanied by recovery in R\&D and domestic innovation. Moreover, the disjunction in EE countries between the accumulation of production vs technology capability could persist for some time due both to the weak technological and R\&D capabilities of enterprises and weak systems of innovation that cannot meet the challenges being posed by the emerging knowledge based economy (Piech and Radosevic, 2006). A shift from technology using to technology generating capabilities is neither automatic nor linear: it is a non-linear, threshold type process, whose progression requires new ranges of institutions and technological capabilities.

Innovation surveys in $\mathrm{EE}$ show that innovation to improve product quality is ranked as important by the highest percentage of firm innovators (Radosevic, 1999). 
Majcen, Radosevic and Rojec (2009) report on research based on 435 foreign subsidiaries in five EE economies. Their study suggests that quality (production capability) is the most important factor in productivity growth. Subsidiaries established through foreign direct investment (FDI) are the most productive firms in EE; hence, the broader relevance of this result, which we want to explore in this context.

Before analysing the relationship between productivity, production and technology capability we examine trends in labour productivity. A recovery and return to growth in EE has been accompanied by rising labour productivity in the industry sector since the mid-1990s (see Figure 1). However, the initial increase in productivity rates was followed by stabilization in all three EE sub-regions (Central and Eastern Europe and the Baltic States, South East Europe, CIS) to a level of just over 5\%. Strong fluctuations in labour productivity growth rates in most of $\mathrm{EE}$ economies suggest that seeming improvements are being driven more by uneven patterns of layoffs, closure of unproductive businesses and reactive restructuring than by continuous technological improvements.

Figure 1: Labour productivity in manufacturing, annual changes 


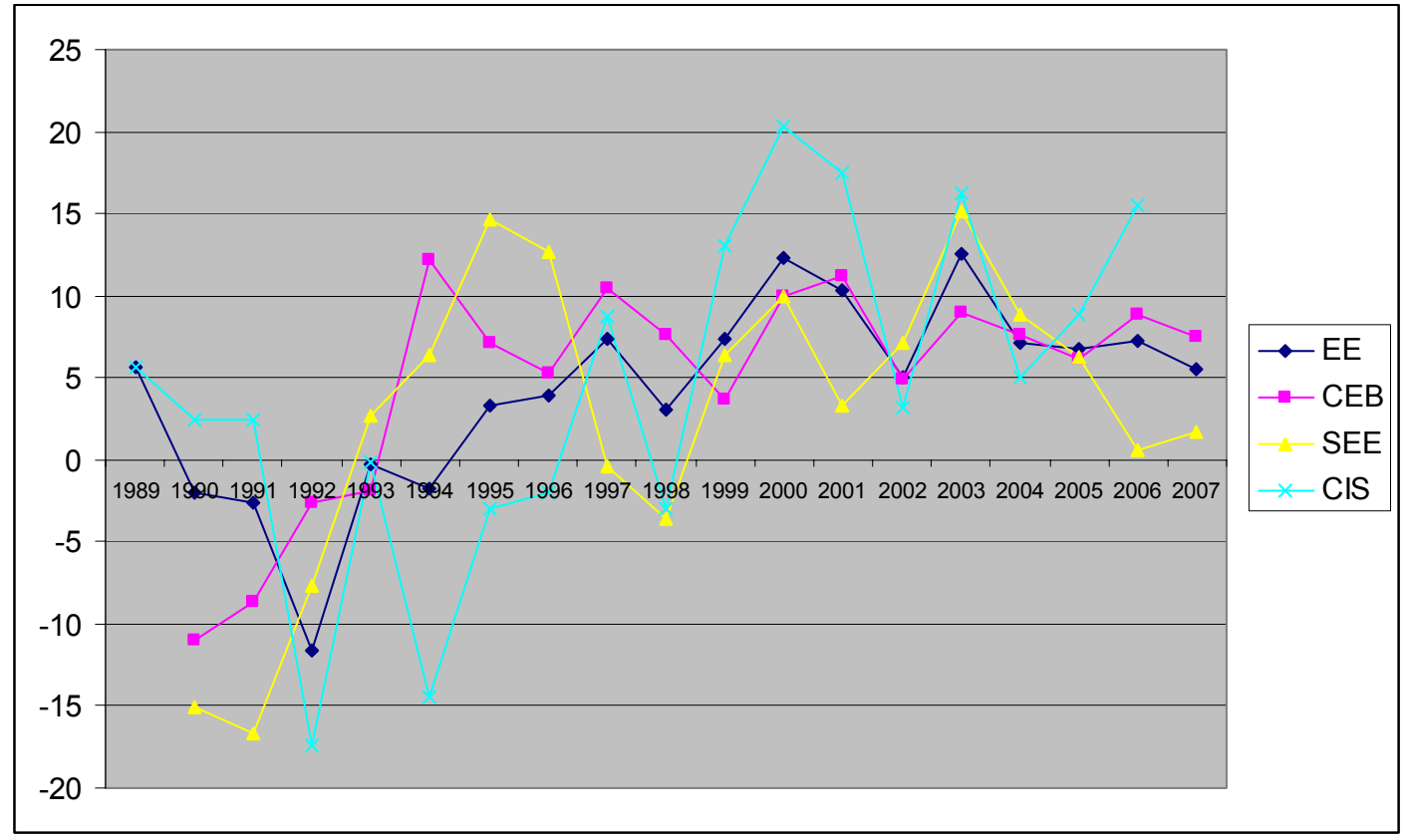

Source: CUBE dataset, EBRD

Legend: CEB: Central Europe and Baltics; SEE: South Eastern Europe; CIS: Commonwealth of Independent States

In the early transition years, productivity growth in EE showed big country differences. But since the early 1990s to 2007, measured in terms of standard deviations, differences in productivity rates between countries have been continuously falling (see Table 1). ${ }^{5}$ This suggests an emerging 'convergence club' which is a bad sign as catching up by the EE to the EU average will require much higher rates of productivity growth and differentiation among individual countries.

Table 1: Average standard deviation of annual changes in productivity 1991-1996 1997-2001 2002-2007

$\begin{array}{lrrr}\text { EE29 } & 13.9 & 8.4 & 6.5 \\ \text { CEE } & 12.9 & 6.2 & 5.1 \\ \text { SEE } & 6.9 & 9.1 & 5.8 \\ \text { CIS } & 12.4 & 7.0 & 7.5^{*}\end{array}$

*2002-2005

Source: CUBE dataset, EBRD

\footnotetext{
${ }^{5}$ Increased average standard deviation for CIS in 2002-2007 period is influenced by 'abnormal' productivity growth in Georgian manufacturing, of 33\% in 2005.
} 
In Section 3 we investigate the role of R\&D in EE productivity growth.

\section{R\&D AND PRODUCTIVITY GROWTH IN EE}

Economic transition in the EE countries has been accompanied by sharp falls in relative R\&D expenditure. As other studies show (Radosevic and Auriol, 1999), downsizing of the R\&D systems in EE has not been linked systematically to any specific demand or supply side factors. It is likely the combination of demand side factors (annual changes in GDP and investments) and supply side policies (budgetary R\&D) that ultimately has shaped trends in $R \& D$ spending. Neither government nor market demand for $R \& D$ could buffer these declines. Figure 2 depicts the sub-regional averages for share of R\&D in GDP and the standard deviation of shares based on individual countries' data.

Figure 2: Share of GERD in GDP in EE and sub-regions and standard deviation for $\mathrm{EE}$ 


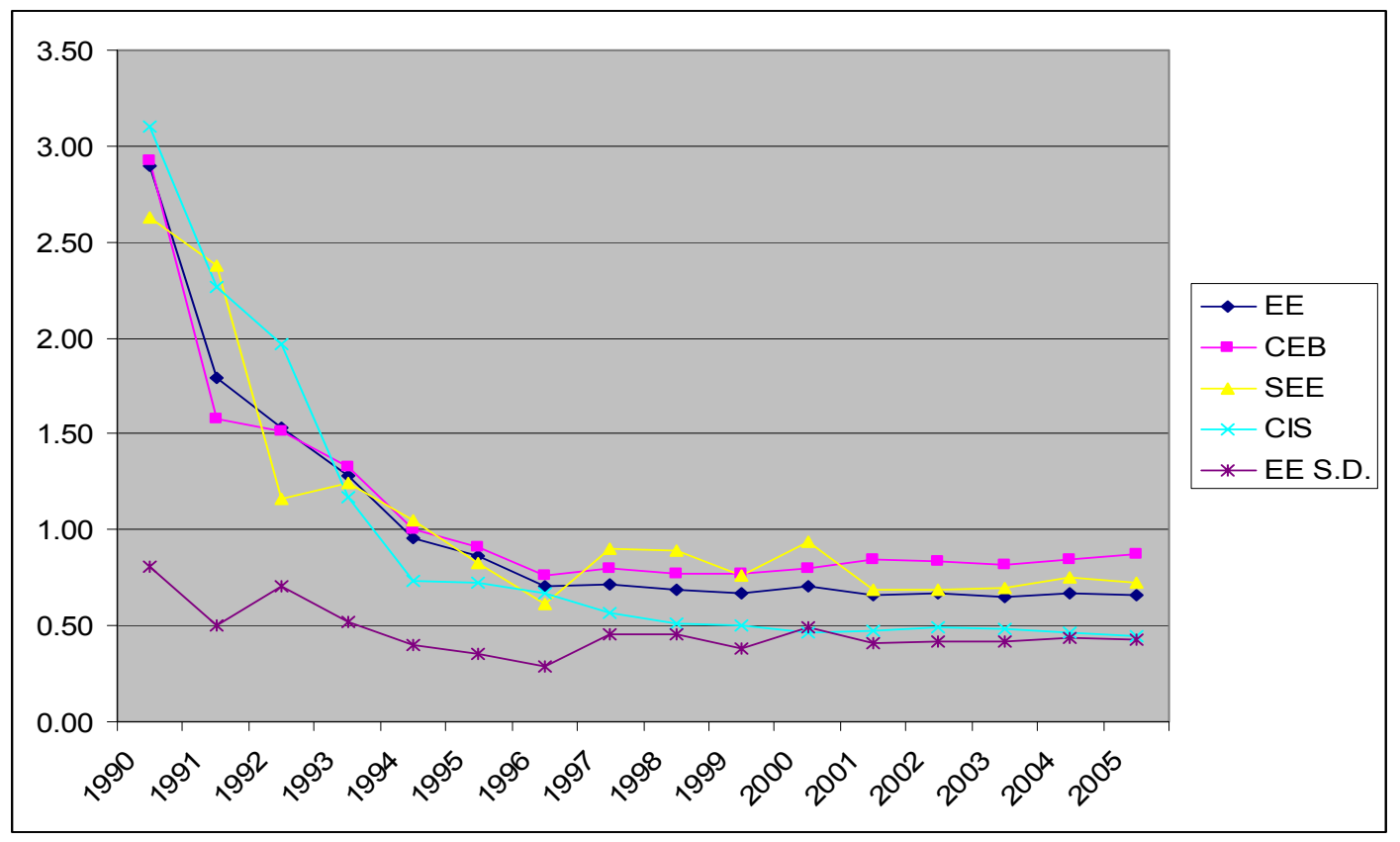

Note: Year to year data are limited prior to 1997 and especially for 10 out of 22 countries for the period 1991-1993.

Source: EBRD (CUBE dataset), Eurostat (New Cronos) and OECD (MSTI)

These data show, first, that the sharp drop in GERD before the mid to late 1990s was followed by stabilization and recovery and, second, similar to the case of productivity (see Table 1) we observe the emerging of a 'convergence club' instead of differentiation among countries. This suggests that the role of R\&D may be peripheral to growth and productivity in EE.

The socialist countries traditionally invested disproportionately high shares of GDP in R\&D (Hanson and Pavitt, 1987), which, to a large extent, was due to the closed nature of these economies, the dominant orientation, especially in the USSR, towards defence technologies, and COCOM restrictions which led to 'reinventions of the wheel'. Before we analyse the issue of (in)efficiencies in the NSI it is interesting to explore to what extent EE countries have been able to shake off this heritage, that is, whether they can be 
differentiated, based on their $\mathrm{R} \& \mathrm{D}$ investments, from countries with similar levels of income. Following Gross and Suhrcke (2000), we test the relationship between GERD and GDP as a function of the level of development.

GERD $/$ GDP $=\alpha+\beta$ GDP pc $+\beta D U M M Y+F E y+\varepsilon$

where

GERD/GDP is the share of R\&D in GDP

Dummies: regional aggregate: EE; SEE: South Eastern Europe; CEB: Central Europe and Baltics; CIS: Commonwealth of Independent States (reference group)

FE_ Fixed effects factor for the years considered.

Table 2 explores this hypothesis. The dependent variable in our regressions is R\&D in GDP. We use the step-wise, ordinary least squares (OLS) method of estimation, with fixed effects, for years in Model 1 and Model 2 (year dummies are not reported in the final presentation of results). Model 1 refers to all 154 countries in the sample; model 2 refers to all EE countries.

Table 2. Share of R\&D in GDP and GDP per capita in East European (EE) and non-EE countries, 1990-2004

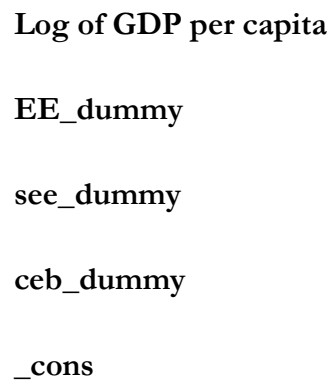

Model_1

$0.48514^{* * *}$

(19.76)

$-0.21380^{* * *}$

$(-3.54)$

\begin{tabular}{rrr} 
& $-0.20761 * * *$ \\
& $(-3.09)$ \\
& & $-0.39115^{* * *}$ \\
& & $(-5.30)$ \\
$-1.19949 * * *$ & & $-1.65814 * * *$ \\
& $(-2.76)$ & \multicolumn{2}{c}{$(-3.95)$} \\
$792 \quad$ & 269 & \\
0.392 & & 0.677
\end{tabular}

Model 1: period 1990-2004 with all countries. Model 2: period 1990-2004 with all EE countries.
Model_2

$0.54061^{* * *}$

(11.39)

0.677 
Source: EBRD (CUBE dataset), and Eurostat (New Cronos) and OECD (MSTI)

Regressing the share of R\&D in GDP on per capita GDP (logged) for all countries and the dummy for EE, produces significant results with moderate explanatory power $(\mathrm{R} 2=0.39)$ though with relatively large coefficients. The EE dummy is significant and negative, indicating that $\mathrm{EE}$ countries under-invest in $\mathrm{R} \& \mathrm{D}$ compared to the rest of the world.

The model for EE with dummies for the sub-groups SEE, CEB and CIS, increases the explanatory power to $68 \%$ and generates significant and negative dummies. The dummy variable coefficients show the extent to which GERD/GDP in CEB and SEE deviates from the CIS, the base category. The negative coefficients suggest that at given levels of GDP, per capita shares of R\&D in GDP for the CEB and SEE are lower than would be expected based on CIS levels. In other words, the level of under-investment in CEB and SEE is significantly higher than in the CIS. This is perhaps to be expected in view of the continuing post-Soviet R\&D system in CIS compared to the systems in CEB and SEE (see Radosevic, 2003). The full magnitude of the drop in demand for R\&D is not reflected in the CIS compared to the other EE countries due to the much stronger policy of preserving the R\&D potential in place in the 1990s.

Our regression results suggest that $R \& D$ plays a relatively small direct role in the current performance of the EE economies (cf. negative dummy for 1990-2004 period). However, we must not ignore the importance of the R\&D system: its role is likely to increase with the return to growth, and its restructuring is a preconditions for further industrial upgrading. In addition, the role of $R \& D$ cannot be evaluated only in terms of its direct contribution to innovation: it contributes also to education and the transfer of 
research methodologies and techniques (Patel and Pavitt, 1997) and is an important factor in absorptive capacity (Cohen and Levinthal, 1989).

Thus, the focus of our analysis of $\mathrm{R} \& \mathrm{D}$ should shift to viewing it as a component of the technological and production capabilities of EE countries. R\&D and innovation are not synonymous, especially in countries that are behind the technology frontier. Therefore, we need to distinguish between $\mathrm{R} \& \mathrm{D}$, innovation and production capabilities, proxied respectively by number of research scientists and engineers (RSE), resident patents, and ISO9000 certificates.

\section{PRODUCTIVITY, PRODUCTION AND TECHNOLOGICAL CAPABILITY}

In this section, we examine whether technological capabilities (R\&D and patents) and production capabilities (ISO9000 certificates) can explain differences in productivity (income per capita) across a sample of countries. We test a model that refers to both countries at the technology frontier and catching up economies whose growth is based either solely on production capability or on a combination of production and technological capability. Within this model using a dummy for EE, we test whether this latter region is underperforming compared to the rest of the world.

The model we use explains productivity levels as a function of investment in $\mathrm{R} \& \mathrm{D}$, innovation and production capability

GNI pc $=\alpha+\beta$ RDPRSNpe $+\beta$ RESPAT $p c+\gamma$ ISO9000 pc/FDI $+\delta$ EE DUMMY

$+\mathrm{FE}$ effects factor $+\varepsilon$ 
where RDPRSN is the number of researchers involved in R\&D per million population, which measures the R\&D intensity of the labour force and can be used as a proxy for the generation of new knowledge (World Bank, World Development Indicators, 2008); RESPAT is the number of resident patent applications per capita (World Development Indicators, 2008); ISO9000pc*FDI is the number of ISO9000 certificates per capita (The ISO Survey of ISO 9000 and ISO 14000 Certificates 1993-2000; 2001-2004 and 20032007, ISO Geneva) divided by share of FDI in GDP (World Development Indicators, 2008). ${ }^{6}$

Unfortunately, we do not have reliable data on RSE in the business enterprise sector (BES), which would have been a better proxy for the innovation orientation of R\&D. EE country data on BES R\&D have several limitations. A high share of extra-mural R\&D, which is inconsistently grouped as BES R\&D or GOV R\&D, makes the use of only BES data problematic. $^{7}$ In addition, use of ISO9000 certification data would require use of the overall R\&D manpower proxy as a counterpart rather than only BES, since a high share of ISO certificates is issued in services, and includes public organizations.

For innovation output we use data on resident patents. National patents are not used extensively in international comparisons as an indicator of national innovation capability. ${ }^{8}$ In this context, US patent data are more common. However, the relevance of US foreign patenting is much less clear in the case of catching up economies. The frequent use of US Patent and Trademark Office data for catching up economies is misleading as world

\footnotetext{
${ }^{6}$ An alternative proxy for ISO certificates, i.e. ISO certificates per capita, is also used in the regression.

${ }^{7}$ For a methodological analysis of these issues see Radosevic and Auriol (1998).

${ }^{8}$ We are actually unaware of any large comparative study based on national patent data. It is still assumed that i) differences in national patent systems, and ii) in quality of national patents are big and do not justify this analysis. We think that the first of these arguments is not justified any more as the process of harmonization in patent legislation has advanced so much that meaningful comparisons are possible today. Differences in quality of resident patents are supposedly present although we have not come across a systematic analysis, which would look at this issue.
} 
technology frontier activities are marginal for these economies. It is not until they reach a certain threshold level that their numbers of US patents increases. Good examples of this are Republic of Korea and Taiwan, whose US patents increased sharply in the late 1980s from levels lower than in the socialist countries during the 1970s (Hu and Jaffe, 2001). Because the technology efforts of these economies are mostly not at the world innovation frontier, the in relatively small numbers of US patents for these economies introduces the danger that small differences in patent numbers - especially over time are over-interpreted. Also, we would expect resident patents to capture imitative innovative effort which is a dominant share of the innovative effort in catching up economies.

Productivity is affected not only by innovation activity, but also by non-innovative or activities related to improvements in production capability. ISO9000 certification is an imperfect but available proxy for these kinds of activities. With the spread of new business models based on contract manufacturing, and fragmented value chains, quality standards have become 'entry tickets' to global production networks (Arndt and Kierzkowski, 2000). For EE countries in particular, ISO certification is indispensable for exports and integration into multinational corporation networks. Hence, we control for number of ISO900 certificates as the degree to which FDI is present in the economy. This variable also captures differences in the sizes of economies and thus the relatively smaller presence of FDI in large economies. We also use the alternative of ISO9000 certificates per capita.

In order to explore whether, given their levels of $\mathrm{R} \& \mathrm{D}$, innovation and quality related activities, EE economies under- or over-perform in terms of productivity, we run regressions with and without the dummies for $\mathrm{EE}$ and $\mathrm{EE}$ sub-regions. 
The results are presented in models $7-12$. The dependent variable in all the regressions is gross national income (GNI) per capita. Our method of estimation is a panel data model with fixed effects (Model 7-10) and step-wise OLS (Model 11 - a reestimation of Model 8 with dummies, and Model 12 - a reestimation of Model 10 with dummies) with fixed effects for years (year dummies are not reported in the final presentation or results) and groups of EE countries

Table 3. Determinants of productivity in EE and non-EE countries, 1993-2005

\begin{tabular}{|c|c|c|c|c|c|c|}
\hline & Model_7 & Model_8 & Model_9 & Model_10 & Model_11 & Model_12 \\
\hline \multirow[t]{2}{*}{ In_researchers_in_rd } & $0.34 * * *$ & $0.21 * * *$ & $0.22^{* * *}$ & $0.16^{* * *}$ & $0.42^{* * *}$ & $0.27 * * *$ \\
\hline & (7.39) & (6.41) & (6.34) & $(6.28)$ & $(20.27)$ & $(13.02)$ \\
\hline \multirow[t]{2}{*}{ ln_patent_resid } & 0.02 & & 0.01 & & & \\
\hline & $(0.47)$ & & $(0.22)$ & & & \\
\hline \multirow[t]{2}{*}{ ln_ISO_FDI } & $0.03 * * *$ & $0.03^{* * *}$ & & & $0.10 * * *$ & \\
\hline & $(6.70)$ & $(7.52)$ & & & $(7.89)$ & \\
\hline \multirow{2}{*}{$\begin{array}{l}\text { Log of ISO standards per } \\
\text { capita }\end{array}$} & & & $0.05^{* * *}$ & $0.05^{* * *}$ & & $0.21 * * *$ \\
\hline & & & (9.44) & $(11.08)$ & & $(16.29)$ \\
\hline \multirow[t]{2}{*}{ cis_dummy } & & & & & $-0.59 * * *$ & \\
\hline & & & & & $(-4.83)$ & \\
\hline \multirow[t]{2}{*}{ see_dummy } & & & & & $-0.55^{* * *}$ & $-0.50 * * *$ \\
\hline & & & & & $(-6.31)$ & $(-5.72)$ \\
\hline \multirow[t]{2}{*}{ ceb_dummy } & & & & & $-0.37 * * *$ & $-0.38 * * *$ \\
\hline & & & & & $(-6.20)$ & $(-6.36)$ \\
\hline \multirow[t]{2}{*}{ _cons } & $7.21 * * *$ & $8.22^{* * *}$ & $8.28 * * *$ & $8.74 * * *$ & $6.33^{* * *}$ & $9.61 * * *$ \\
\hline & $(21.94)$ & $(33.64)$ & $(32.10)$ & $(45.92)$ & $(17.29)$ & $(38.13)$ \\
\hline Number of observations & 364 & 449 & 374 & 471 & 449 & 471 \\
\hline $\mathbf{R} 2$ & 0.313 & 0.243 & 0.349 & 0.329 & 0.755 & 0.762 \\
\hline
\end{tabular}

The models including all countries (7-10) have significant coefficients for number of $\mathrm{R} \& \mathrm{D}$ personnel and for ISO certificates - based on both proxies (8 and 10) while the coefficient of patents is not significant. Models 11-12 including the dummies for EE sub- 
regions have improved explanatory power $(\mathrm{R} 2=75 \%)$ and significantly higher coefficients including negatively significant regional dummies. 'The negative coefficients of the dummies for all three EE sub-regions suggest that based on number of R\&D personnel and ISO certificates, EE countries have lower levels of GNI per capita compared to the rest of the world. The models that include sub-regional dummies (11 and 12) show improved explanatory power confirming that inefficiency of the NSI characterizes all EE sub-regions, although the CIS dummy is not significant in model 12 when we use an alternative indicator for production capability. Sub-regional dummy coefficients are ranked in order from CEB to CIS suggesting the ranking of inefficiency in the broad NSI.

Productivity does not change substantially when innovation capability is proxied by resident patents. This suggests that resident patents do not contribute to explaining productivity levels over time,$^{10}$ whereas ISO certification, in both specifications, as a proxy for production capability significantly contributes to explaining the differences in productivity. This confirms the importance of capturing both $\mathrm{R} \& \mathrm{D}$ and production capability for understanding productivity differences across countries. In a catching up context, R\&D denotes absorptive rather than innovative capability. This is in line with the argument about the two sides to R\&D proposed by Cohen and Levinthal (1989). As our sample includes both developed and catching up economies a significant R\&D coefficient denotes the importance of both new knowledge generation at the world technology frontier and absorptive capacity for catching-up economies.

\footnotetext{
${ }^{9}$ Note that models 7-10 are estimated using fixed effects and therefore time-invariable dummies are excluded. The variable Patent_resid is locked in in regressions 7 and 9 to show the differences in the fit of other regressions.

${ }^{10}$ We checked whether there was significant correlation between R\&D and patents which might capture similar dimensions of technological effort. However, the correlation is only 0.23 and is insignificant.
} 
The relevance of this model (Table 4) is confirmed also in the models with only EE countries, whose explanatory power is increased. In all the models except model 7.1, both the coefficient of production capability and the R\&D coefficient are significant. As in Table 3 the coefficients of patents are not significant.

\begin{tabular}{|c|c|c|c|c|c|c|}
\hline \multicolumn{7}{|c|}{$\begin{array}{l}\text { Table 4. Determinants of productivity in EE countries, 1996-2005 } \\
\text { (Reestimation of table } 3 \text { for EE countries) }\end{array}$} \\
\hline & Model_7.1 & Model_8.1 & Model_9.1 & Model_10.1 & Model_11.1 & Model_12.1 \\
\hline \multirow[t]{2}{*}{ ln_researchers_in_rd } & 0.17 & $0.20^{*}$ & $0.22 * *$ & $0.23^{* *}$ & $0.08^{* *}$ & $0.14 * * *$ \\
\hline & $(1.45)$ & (1.81) & (2.16) & (2.44) & (2.11) & (3.86) \\
\hline \multirow[t]{2}{*}{ ln_patent_resid } & 0.10 & & 0.10 & & & \\
\hline & $(1.30)$ & & $(1.48)$ & & & \\
\hline \multirow[t]{2}{*}{ In_ISO_FDI } & $0.09 * * *$ & $0.08^{* * *}$ & & & $0.11^{* * *}$ & \\
\hline & (8.90) & (9.69) & & & $(10.63)$ & \\
\hline \multirow{2}{*}{$\begin{array}{l}\text { Log of ISO patents per } \\
\text { capita }\end{array}$} & & & $0.10^{* * *}$ & $0.10^{* * *}$ & & $0.14^{* * *}$ \\
\hline & & & $(12.00)$ & $(12.80)$ & & $(19.82)$ \\
\hline \multirow[t]{2}{*}{ see_dummy } & & & & & $-0.15^{* *}$ & $-0.26^{* * *}$ \\
\hline & & & & & $(-2.53)$ & $(-7.15)$ \\
\hline \multirow[t]{2}{*}{ ceb_dummy } & & & & & $0.16^{* * *}$ & \\
\hline & & & & & (2.97) & \\
\hline \multirow[t]{2}{*}{ _cons } & $8.32^{* * *}$ & $8.65^{* * *}$ & $8.01 * * *$ & $8.46^{* * *}$ & $9.68^{* * *}$ & $9.63 * * *$ \\
\hline & (9.01) & $(10.24)$ & $(10.18)$ & $(11.79)$ & $(25.67)$ & $(34.31)$ \\
\hline Number of observations & 121 & 126 & 121 & 126 & 126 & 126 \\
\hline R2 & 0.478 & 0.497 & 0.614 & 0.625 & 0.827 & 0.832 \\
\hline
\end{tabular}

Note: Dependent variable in all regressions: GNI per capita. Method of estimation: panel data model with fixed effects $\{$ Model 7-10\} and step-wise OLS in Model 11 \{reestimation of Model 8 with dummies\} and Model 12 \{reestimation of Model 10 with dummies\} with fixed effects for years \{dummies for years are not reported in the final presentation $\}$ and groups of EE countries

When we include in the models sub-regional dummies (11_1 and 12_1) the size of the coefficients of production capability increases and the explanatory power improves even more, to above $80 \%$. It is interesting that compared to the CIS countries, the CEB dummy is significantly positive in model 11_1, again suggestive of somewhat higher efficiency of the broad NSI in this group of countries. 


\section{TESTING THE (IN)EFFICIENCY OF NARROW NSI IN EE}

Due to the multifaceted nature of S\&T inputs and outputs, the issue of productivity in narrow national innovation systems is complex. The outputs of innovation activities include both products such as patents and papers, and tangibles such as machinery and equipment, and also a wide range of know-how (capabilities) and skills, all of which need to be considered in trying to understand productivity in relation to innovation. Any indicator is inevitably very partial and can be understood only in a specific institutional context.

One way to explore the inefficiency of narrow NSI is to relate S\&T outputs to inputs. To do this, we run regressions that test the relationship between S\&T publications/resident patents as the output variable, and R\&D employment as the input variable and include three control variables (per capita GNI, share of high tech in exports, and ISO9000 certificates) to control for structural biases that interfere in the relationship between S\&T inputs and outputs. The R\&D systems in more developed countries enjoy spillover effects from their more developed division of labour and greater availability of specialty services. And this cumulated advantage affects the efficiency of narrow NSI. Countries differ in terms of industry structure, which affects the relationship between R\&D inputs and outputs. Those countries that are more specialized in high tech sectors and are exporters of high tech products are more likely to have higher shares of patents. Also, the relationship between R\&D inputs and outputs may be affected by a country's position in relation to the technology frontier. We can expect better developed production capability compared to innovation capability in catching up 
or laggard economies will negatively affect this relationship between S\&T inputs (R\&D employment) and outputs (patents). As we are interested in efficiency, irrespective of structure, we need to control for these structural biases.

\begin{tabular}{|c|c|c|c|c|c|c|}
\hline & Model_13 & Model_14 & Model_15 & Model_16 & Model_17 & Model_18 \\
\hline & \multicolumn{3}{|c|}{ Y (S\&T publications) } & \multicolumn{3}{|c|}{ Y (Patents) } \\
\hline \multirow[t]{2}{*}{ ln_researchers_in_rd } & $0.28^{* * *}$ & $0.27 * * *$ & $0.22^{* *}$ & 0.10 & 0.11 & 0.17 \\
\hline & (2.75) & (2.69) & (2.26) & (0.89) & (0.99) & (1.22) \\
\hline \multirow[t]{2}{*}{ ln_HiTech_exp2 } & & $0.12^{* * *}$ & $0.09^{* *}$ & & -0.05 & $-0.11 *$ \\
\hline & & (3.04) & (2.16) & & $(-0.90)$ & $(-1.80)$ \\
\hline \multirow[t]{2}{*}{ ln_gni_pc_ppp } & & & $0.14^{* *}$ & & & $0.26^{*}$ \\
\hline & & & (2.23) & & & $(1.87)$ \\
\hline \multirow[t]{2}{*}{ In_iso_pc } & & & & & & $-0.06^{* * *}$ \\
\hline & & & & & & $(-3.22)$ \\
\hline \multirow[t]{2}{*}{ _cons } & $4.75^{* * *}$ & $4.69^{* * *}$ & $3.73^{* * *}$ & $5.30^{* * *}$ & $5.30^{* * *}$ & 1.99 \\
\hline & (6.32) & (6.45) & (4.49) & (6.51) & (6.51) & (1.27) \\
\hline Number of observations & 126 & 124 & 124 & 129 & 129 & 121 \\
\hline R2 & 0.064 & 0.137 & 0.175 & 0.007 & 0.014 & 0.146 \\
\hline
\end{tabular}

The results of our regressions (Table 5, models 13-15) suggest that there is positive relationship between inputs ( $\& \& D$ employment) and outputs (S\&T papers) although the explanatory power is quite small ( $\mathrm{R} 2=6.4 \%$ ). If we control for developmental (per capita GNI) and structural (high-tech exports) biases, the explanatory power of the model improves and all explanatory variables are significant. This confirms that the outputs of science systems (S\&T papers) are influenced by both structural features and developmental spillovers.

Models 16-18 show that R\&D does not explain innovation capability: the coefficient of $\mathrm{R} \& \mathrm{D}$ employment is not significant. ${ }^{11} \mathrm{R} \& \mathrm{D}$ employment remains

${ }^{11}$ This is compatible with the low correlation coefficient of R\&D and patents observed in Section 3. 
insignificant when the control variables are added up, although these variables are significant. A significant negative coefficient of ISO9000 certificates suggests that innovation and production capabilities are not complementary. Better developed production capability does not automatically lead to higher technological capability. A negative coefficient of high-tech export, significant only at the $10 \%$ level, is the only slightly puzzling result. We think that it reflects weaknesses in OECD R\&D based on the high tech classification of industries which is applied also to catching up economies. These sectors in EE are not actually R\&D intensive, for example, CEB economies are specialized in low value added segments of high tech sectors. Thus, the R\&D intensity of EE electronics is lower than the average for manufacturing (see Srholec, 2006 for evidence).

Models 13_1-18_1 including all countries (Table 6) show similar results, but much stronger explanatory power (especially in relation to R\&D) and higher coefficients. The coefficient of high tech exports is positive and significant, while the coefficient of the variable for production capability is insignificant. The models that include patents as the dependent variable have significant coefficients for high tech. In the model for only EE the coefficient is negative. Production capability for all countries is insignificant but for EE is strongly negatively significant. These differences suggest some major EE specificities:

$\mathrm{R} \& \mathrm{D}$ employment is a weaker determinant of $\mathrm{S} \& \mathrm{~T}$ publications in $\mathrm{EE}$ which suggest possibly inefficiencies in the narrow NSI;

a negative relationship between patents and high tech exports indicates an EE specific mode of global integration through low value added segments in high tech sectors, as indicated elsewhere (see Srholec, 2006; Kaderabkova, 2006); a negative relationship between innovation (patents) and production capability (ISO9000 certificates) is suggestive of a gap between these two types of 
capabilities i.e. progress in production capability may not be sufficient for progress in innovation capability.

Table 6. Determinants of S\&T publications and Patents in all (EE and non-EE) countries during 1990-2005 \{Reestimation of Table 5 for all countries\}

\begin{tabular}{|c|c|c|c|c|c|c|}
\hline & Model_13_1 & Model_14_1 & Model_15_1 & Model_16_1 & Model_17_1 & Model_18_1 \\
\hline Dependent variable & S\&T papers & S\&T papers & S\&T papers & Patents & Patents & Patents \\
\hline \multirow[t]{2}{*}{ ln_researchers_in_rd } & $0.57 * * *$ & $0.54 * * *$ & $0.43^{* * *}$ & $0.42 * * *$ & $0.43^{* * *}$ & $0.52^{* * *}$ \\
\hline & (12.98) & (13.13) & $(10.10)$ & (7.44) & (7.42) & (8.29) \\
\hline \multirow[t]{2}{*}{ ln_HiTech_exp2 } & & $0.15^{* * *}$ & $0.10^{* * *}$ & & 0.08 & $0.10^{*}$ \\
\hline & & (5.32) & $(3.75)$ & & (1.63) & $(1.85)$ \\
\hline \multirow[t]{2}{*}{ ln_gni_pc_ppp } & & & $0.35^{* * *}$ & & & 0.00 \\
\hline & & & (6.62) & & & $(0.01)$ \\
\hline \multirow[t]{2}{*}{ ln_iso_pc } & & & & & & -0.01 \\
\hline & & & & & & $(-0.69)$ \\
\hline \multirow[t]{2}{*}{ _cons } & $3.56^{* * *}$ & $3.41 * * *$ & $0.99 * *$ & $3.63^{* * *}$ & $3.43^{* * *}$ & $2.72^{* * *}$ \\
\hline & $(11.48)$ & $(11.52)$ & $(2.16)$ & (8.97) & (8.07) & $(2.76)$ \\
\hline Number of observations & 435 & 407 & 407 & 403 & 385 & 361 \\
\hline $\mathbf{R} 2$ & 0.318 & 0.400 & 0.469 & 0.142 & 0.156 & 0.224 \\
\hline
\end{tabular}

Note: Dependent variable in Models 13_1-15_1 is S\&T publications; dependent variable in Models 16_1-

$18 \_1$ is patents. Method of estimation: fixed effects panel data model

Next, we test the previous two models, for all countries and with EE dummies (Table 7).

The dependent variable in Models 19 and 21 is S\&T publications; the dependent variable in Models 20 and 22 is patents. Models 19 and 20 include all countries; Models 21 and 22 are all countries but with sub-regional dummies. The method of estimation is step-wise OLS with fixed effects for years and groups of EE countries.

Table 7. Determinants of S\&T publications and Patents in all (Model 19 and 20) and EE (Model 21 and 22) countries, 1996-2005

\begin{tabular}{|c|c|c|c|c|}
\hline & Model_19 & Model_20 & Model_21 & Model_22 \\
\hline Dependent variable & $\begin{array}{c}\text { S\&T } \\
\text { publications }\end{array}$ & Patents & $\begin{array}{c}\text { S\&T } \\
\text { publications }\end{array}$ & Patents \\
\hline \multirow[t]{2}{*}{ ln_researchers_in_rd } & $0.98^{* * *}$ & $0.94 * * *$ & $1.50^{* * *}$ & 0.04 \\
\hline & $(7.95)$ & (7.18) & (5.40) & $(0.12)$ \\
\hline ln_gni_pc_ppp & $-0.50 * * *$ & & $1.19 * * *$ & \\
\hline
\end{tabular}




\begin{tabular}{|c|c|c|c|c|}
\hline & $(-2.83)$ & & (3.31) & \\
\hline \multirow[t]{2}{*}{ ln_HiTech_exp2 } & $0.34 * * *$ & $0.84 * * *$ & & \\
\hline & (3.30) & (5.95) & & \\
\hline \multirow[t]{2}{*}{ ln_iso_pc } & & $-0.20 * * *$ & & $0.18^{* *}$ \\
\hline & & $(-3.37)$ & & $(2.31)$ \\
\hline \multirow[t]{2}{*}{$\mathbf{E E}$} & $-1.36 * * *$ & $-0.68 * * *$ & & \\
\hline & $(-6.53)$ & $(-2.66)$ & & \\
\hline \multirow[t]{2}{*}{ ceb_dummy } & & & $-1.04 * * *$ & $-4.32^{* * *}$ \\
\hline & & & $(-3.81)$ & $(-8.88)$ \\
\hline \multirow[t]{2}{*}{ see_dummy } & & & & $-3.75^{* * *}$ \\
\hline & & & & $(-7.26)$ \\
\hline \multirow[t]{2}{*}{ _cons } & $4.98^{* * *}$ & $-3.72 * * *$ & $-14.37 * * *$ & $11.13^{* * *}$ \\
\hline & (4.30) & $(-2.84)$ & $(-4.53)$ & (3.81) \\
\hline Number of observations & 400 & 358 & 124 & 121 \\
\hline $\mathbf{R} 2$ & 0.326 & 0.343 & 0.325 & 0.490 \\
\hline \multicolumn{5}{|c|}{ note: $* * * \mathrm{p}<0.01, * * \mathrm{p}<0.05, * \mathrm{p}<0.1$} \\
\hline \multicolumn{5}{|c|}{$\begin{array}{l}\text { Estimation: step-wise OLS with fixed effects for years and groups of EE countries } \\
\text { \#Note: In model } 21 \text { the CEB_dummy is the only significant dummy left in the step-wise OLS estimation and therefore } \\
\text { reflects the relationship for the CEB group of countries against the rest of the EE countries in the sample. While in Model } 22 \\
\text { both dummies are significant and therefore the base group here is CIS countries. }\end{array}$} \\
\hline
\end{tabular}

In both models (19 and 20) with EE dummies, these are highly significant and negative indicating that compared to the number of researchers, EE R\&D systems generate fewer S\&T publications and patents than the rest of the world. Also, for patents, the control variable level of development is insignificant, and not reported, while structural bias towards high tech is positively significant. A negative and significant coefficient of production capability (ISO9000 per capita) indicates that production and innovation capability are not complements, that is, developed production capability does not automatically lead to innovation capability. We do not have a simple explanation for the negative coefficient of GNI per capita in Model 19 since it is positive in Models 15 and 15_1. It may be that the aggregate dummy for EE is too rough a proxy given the diverse of growth experiences in early transition but not later periods. This possibility is confirmed in Model 21 which includes only EE countries and sub-regional dummies and the control variable GNI per capita is significant and positive. This model shows only the CEB dummy as significant, suggesting that compared to the number of researchers, income levels and high tech orientation, CEB has generated fewer S\&T publications 
compared to the other two sub-regions. In Model 22 for patents, this result applies to both CEB and SEE, compared to the rest of the EE (CIS), which suggests that CEB and in part SEE produce lower numbers of publications and patents given their R\&D employment, income levels and high-tech orientation. Does this suggest that their narrow NSI are more inefficient than those of the CIS? We believe that the narrow NSI in CIS are still largely post-Soviet type systems which means that they continue to be more autonomous, and have been less exposed to restructuring, that is, to demand shocks, due to the persistence of the policy of 'preservation of S\&T potential'. The result is that the R\&D systems of CIS, especially Russia, Ukraine and Belarus, produce higher numbers of S\&T publications and domestic patents, but these outputs are not necessarily linked to the new, radically transformed demand for local R\&D and local innovation. So, the notion of (in)efficiency cannot be understood outside the specific institutional context of the post-Soviet (CIS) and the EU-ized (CEB and partly SEE) R\&D systems. This is in contrast to higher efficiency or lower inefficiency of the broad NSI in CEB compared to the other two sub-regions.

\section{CONCLUSIONS AND POLICY IMPLICATIONS}

Innovation and technical change are the main drivers of economic growth although it is difficult empirically to show the link between them (OECD, 2001). Differences in the abilities of countries to generate technical change are crucial for determining the speed and nature of the catching-up process. In this paper, we have tried to address some of the factors behind the differences in the drivers of productivity by looking primarily at the impact of production and technology (innovation and production) capabilities of EE.

Our analysis shows that the EE has lost the advantages of size of $R \& D$, inherited from the socialist period and as pointed out in EC (2004), the problem of, low efficiency 
of their innovation systems ( $\& \& D$, education and vocational training systems) has emerged.

We can draw several conclusions. First, EE countries have lost some advantage in terms of the size of $\mathrm{R} \& \mathrm{D}$. Second, production capability in combination with $\mathrm{R} \& \mathrm{D}$ employment explains the productivity differences within our sample. Third, EE countries have lower levels of productivity than might be expected given their R\&D capacities and production capabilities, which points to possible inefficiencies in their conversion into productivity. Fourth, patents as proxies for innovation capability are not significant for explaining productivity levels in EE and other economies. This confirms our proposition that growth in EE is driven by production, not innovation capabilities. Moreover, results for all countries including EE suggest that production capability does not automatically lead to innovation capability. Fifth, productivity of the narrow NSI, proxied by papers and patents, is explained satisfactorily by the numbers of researchers in all countries including EE. However, the efficiency of the process of conversion is lower in EE. Sixth, we conclude that there are inefficiencies in both the narrow and the broad NSI.

Our conclusions suggest that policy in EE should pay focus more on the distinction between technology generation and use, that is, production and absorptive capabilities.

Production capability in combination with $\mathrm{R} \& \mathrm{D}$ capabilities is a satisfactory explanation for productivity differences among OECD and EE countries. Our results point to the importance of quality and intra-firm productivity-enhancing activities for growth and catch-up, and to the role of R\&D capabilities in knowledge generation at the world technology frontier and in the mechanisms for acquiring absorptive capabilities. From a methodological point of view, our study shows that catching up and technology frontier activities cannot be measured by a single metric. Catching up in EE continues to located within production capability and, hence, metrics such as the European 
Innovation Scoreboard (EC, 2008) which are based on world frontier activities, are inadequate as benchmarks.

Overall, EE countries are inefficient both at converting their $R \& D$, innovation and production capabilities into appropriate levels of productivity, and converting their $\mathrm{R} \& \mathrm{D}$ and production capabilities into outputs such as $\mathrm{S} \& \mathrm{~T}$ papers and resident patents. We define these problems respectively as inefficiencies in broad and narrow NSI.

The inclusion of sub-regional dummies in the models for determining productivity, suggest that inefficiency of the broad NSI is a common regional characteristic, in ascending order from CEB, to SEE, to CIS. Inefficiency of the narrow NSI also applies to all three subregions although as it is specific to the institutional context the ranking becomes post-Soviet (CIS) to EU-ized R\&D systems (CEB) with the SEE a kind of intermediate case.

Our analysis points to the problem of inefficient NSI in EE, but cannot necessarily detect the causes for these inefficiencies. To do this would require in depth country and inter-country comparisons. Existing analyses (Radosevic, 2006; Nemet, 2009) suggest that the problems lie not only in the S\&T systems themselves, but in the broader context of demand for technology. This applies particularly to the relationships between small and large firms, and the integration of foreign firms into the local economy (McGowan et al., 2004).

Our findings point to the important distinction between technology using (production) vs technology ( $\mathrm{R} \& \mathrm{D}$ and innovation) capabilities and has several implications for policy.

First, they point to importance of production capability, that is, intra-firm productivity or non-R\&D activities. This aspect of policy, which is addressed only through vocational training, is essential for improving the absorptive capabilities of the EE. By improving their absorptive or technology using capabilities, firms can move to 
technology adoption and developing activities. A prominent policy feature of EE is the lack of vision related to its learning (education/training) systems, that is, poor response through policy to improving firm specific production capabilities.

Second, a key challenge for EE at firm level, is how firms can make the transition from mastery of production to technological (R\&D and innovation) capabilities. This process is not automatic or linear and requires changes both within firms and in the narrow NSI or innovation infrastructure, as well as changes in the broad NSI.

Third, a re-orientation of EE R\&D systems from the current exclusive focus on knowledge generation to knowledge diffusion and absorption orientation is required. The capacity to diffuse knowledge throughout the economy is essential for catching-up in the knowledge based economy. By embracing the additional functions of knowledge diffusion (supply side), R\&D systems would better match changing demand for innovation and technology, generated through the broad NSI.

To summarize, our analysis points to the gap between the production and technology determinants of productivity in EE, and the inability of policy to close this gap. Policies that would help to close this gap are not confined only to the narrow NSI or oriented only towards the generation of new knowledge: they also need to embrace the knowledge absorption and diffusion functions of R\&D systems, and assist in the integration of narrow and broad NSI through effective, demand-oriented measures.

Finally, we should point to some limits of our analysis. It is primarily a quantitative analysis whose purpose is not to substitute but to complement comparative qualitative institutional analyses. It suffers from the usual tension between concepts and their imperfect proxies.

\section{REFERENCES}


Abrunhosa, Ana and Moura E Sa, Patricia (2008) "Are Tqm Principles Supporting

Innovation in the Portuguese Footwear Industry?" Technovation, 28(4), pp. 208-21.

Alam, A.; Anos Casero, P.; Khan, F. and Udomsaph, C. (2008) Unleashing Prosperity:

Productivity Growth in Eastern Europe and the Former Soviet Union. Washington, D.C: World Bank.

Arndt S. and H. Kierzkowski, eds. (2000), Fragmentation and International Trade, Oxford

University Press, Oxford and New York.

Arnold, E. ; Bell, M.; Bessant, J. and Brimble, P. (2000). "Enhancing Policy and Institutional

Support for Industrial Technology Development of Thailand. The Overall Policy Framework and the Development

of the Industrial Innovation System." Technopolis, Brighton, December.

Bell, M. (1997), 'Technology transfer to transition countries: are there lessons from the experience of the post-war industrializing countries?', in Dyker, D. (ed.), Technology of Transition: S\&̋T Policies for Transition Countries, CEU Press, Budapest, pp. 63-94.

Bell, M. and Pavitt, K. (1993), 'Technology Accumulation and Industrial Growth: Contrasts Between Developed and Developing Countries', Industrial and Corporate Change, 2 (2), 157-210.

Berg, Andrew; Borensztein, Eduardo R; Sahay, Ratna and Zettelmeyer, Jeromin (1999).

"The Evolution of Output in Transition Economies - Explaining the Differences." IMF Working Paper, 1999, WP/99/73.

Campos, Nauro F. and Coricelli, Fabrizio (2002). "Growth in Transition: What We Know, What We Don't, and What We Should." Journal of Economic Literature, American Economic Association, 40(3), pp. 793-836.

Chakravarti, Shamit; Gupta, Sanjeev; Leruth, Luc and Mello, Luiz de (2005). "Transition Economies: How Appropriate Is the Size and Scope of Government?," International Monetary Fund, IMF Working Papers: 01/55, 43 pages.

Cohen, W. and Levinthal, D. (1989) "Innovation and Learning: The Two Faces of R\&D." Economic Journal, 99, pp. 569-96.

Crafts, Nicholas and Kaiser, Kai. (2004) "Long-Term Growth Prospects in Transition Economies: A Reappraisal." Structural Change and Economic Dynamics, 2004, 15(1), pp. 101-18. 
Christofferson, P. and P. Doyle (19998): 'From Inflation to Growth: Eight Years of Transition', IMF Working Paper, WP98/100, International Monetary Fund, Washungton.

Dahlman, C. J.; Ross-Larson, B. and Westphal, L. E. (1987) "Managing Technological

Development: Lessons from the Newly Industrializing Countries." World Development, 1987, 15(6), pp. $759-75$.

Dutrenit, Gabriela (2000). "Learning and Knowledge Management in the Firm: From

Knowledge Accumulation to Strategic Capabilities," New Horizons in the Economics of Innovation.

Cheltenham, U.K. and Northampton, Mass.: Elgar; and Williston, Vt., 2000, xiv.

EC (2004). "Commission Recommendations on the 2004 Update of the Broad Guidelines of the Economic Policies of the Member States and the Community (for the 2003-2005

Period)(Presented in Accordance with Article 99(2) of the Ec Treaty)," Brussels: European Commission.

_ (2008) "Comparative Analysis of Innovation Performance," European Innovation Scoreboard. Brussels: European Commission - (2002) "Report on Research and Development, Economic Policy Committee, Working Group on R\&D," Brussels: European Commission.

Edquist, Charles ed. (1997) Systems of Innovation: Technologies, Institutions and Organizations. London: Pinter Publishers.

Evenson, E.R. and Westphal, E.L. (1995), Technological Change and Technology Strategy, in Behrman, J. and Srinivasan, T.N. Handbook of Development Economics, Vol. III, Elsevier Science BV, 1995, pp. 2211-2299.

Falcetti, E.; Lysenko, T. and Sanfei, P. (2006). " Reforms and Growth in Transition: ReExamining the Evidence." Journal of Comparative Economics, 34 pp. 421-45.

Fischer, Stanley; Sahay, Ratna and Vegh, Carlos (1998). "From Transition to Market -

Evidence and Growth Prospects." IMF Working Paper, 1998, WP/98/52.

Freeman, C (1987). Technology Policy and Economic Performance: Lessons from Japan. London: Pinter. 
Freeman, C. (2006) "Catching-Up" and Innovation Systems: Implications for Eastern Europe', In K. Piech, S. Radosevic (eds.), Knowledge based economy in central and eastern Europe: Countries and Industries in a Process of Change, Palgrave, London

Gross, D. and Suhrcke, M. (2000) "Ten Years After: What Is Special About Transition Countries." EBRD (European Bank for Reconstruction and Development) Working Paper, 2000, 56

Hanson P. and K. Pavitt (1987), The Comparative Economics of Research Development and Innovation in East and West, Francis and Taylor

Havrylyshyn, Oleh (2001) Recovery and growth in Transition: A Decade of Evidence. IMF Staff Papers. Vol. 48, Special Issue, Washington, IMF, pp. 53-87,

Havrylyshyn, Oleh. (2008) "Growth Recovery in CIS Countries: The Sufficient Minimum Threshold of Reforms." Comparative Economic Studies, 50(1), pp. 53-78.

Havrylyshyn, Oleh; Rooden, Ron van and Izvorski, Ivailo. (1998), "Recovery and Growth in Transition Economies 1990-97--a Stylized Regression Analysis," International Monetary Fund, IMF Working Papers: 98/141, 1998.

Hu, A. and Jaffe, A. (2001) "Patent Citations and International Knowledge Flow: The Case of Korea and Taiwan." NBER Working Paper, 2001, w8528.

Kaderabkova, A. (2006) . "Skills for Knowledge-Based Economy in Central European Countries," K. Piech and S. Radosevic, The Knowledge-Based Economy in Central and East European Countries: Countries and Industries in a Process of Change. London: Palgrave Macmillan.

Katz, J. (ed.) (1987), Technology Generation in Latin America, Macmillan, London.

Lall, Sanjaya (1990) Building Industrial Competitiveness in Developing Countries Paris, France:

Development Centre of the Organisation for Economic Co-operation and Development.

Lederman , Daniel and Maloney, William F. (2003). "R\&D and Development." World Bank Policy Research Working Paper, April 2003, 3024.

Lundvall, Bengt-Ake (1992). "National Systems of Innovation: Towards a Theory of Innovation and Interactive Learning: Introduction," National Systems of Innovation: Towards a Theory of Innovation and Interactive Learning. London: Pinter; distributed in the U.S. and Canada by St. Martin's Press, New York, pp.1-19. 
Lypez-Mielgo, Nuria; Montes-Peyn, Jose M. and Vazquez-Ordas, Camilo J (2009a). "Are

Quality and Innovation Management Conflicting Activities?" Technovation, 2009, 29(8), pp. 537-45. Lypez-Mielgo, N. ; Montes-Peón, J.M. and Vázquez-Ordás, C. (2009b). "Innovation, Iso Certification, and Quality Normalization in the Food Industry," R. Rama, Handbook of Innovation in the Food and Drink Industry. New York: The Haworth Press, 171-209.

Majcen, B., S. Radosevic, M. Rojec (2009) Nature and determinants of productivity growth of foreign subsidiaries in Central and East European countries, Economic System, 33 (2009) 168-184

McGowan, F. ; Radosevic, S. and von Tunzelmann, N (2004). eds. The Emerging Industrial Structure of the Wider Europe. London: Routledge.

Mickiewicz, Tomasz (2005). Economic Transition in Central Europe and the Commonwealth of Independent States. Houndmills, U.K. and New York: Palgrave Macmillan.

Nemet, Gregory F (2009). "Demand-Pull, Technology-Push, and Government-Led Incentives for Non-Incremental Technical Change." Research Policy, 2009, 38(5), pp. 700-09.

Niosi, Jorge (2002). "National Systems of Innovations Are 'X-Efficient' (and X-Effective): Why Some Are Slow Learners." Research Policy, 31(2), pp. 291-302.

OECD. The Sources of Economic Growth in OECD Countries, Paris: OECD, 2001

OECD. "Dynamising National Innovation Systems," Paris: OECD, 2002.

Patel, Parimal; Pavitt, Keith (1997) "National Innovation Systems: Why They Are Important, and How They Might Be Measured and Compared," In Jasanoff, Sheila (ed).Comparative Science and Technology Policy. Cheltenham, U.K. and Lyme, N.H.: Elgar Reference Collection. International Library of Comparative Public Policy, vol. 5. Elgar,pp, 297-315.

Piech, K. and Radosevic, S. eds. (2006) Knowledge Based Economy in Central and Eastern Europe: Countries and Industries in a Process of Change. London: Palgrave.

Radosevic S (1999). 'Patterns of innovative activities in countries of central and eastern Europe : an analysis based on comparison of innovation surveys', SPRU Electronic Working Papers Series, No,. 35, p48. , http://www.sussex.ac.uk/Units/spru/publications/imprint/sewps/sewp35/sewp35.pdf 
Radosevic S. (2003) 'Patterns of Preservation, Restructuring and Survival: Science and technology policy in Russia in the post-Soviet era', Research Policy 32(6): 1105-24, 2003.

Radosevic, S. (2006), "Domestic Innovation Capacity - Can CEE Governments Correct FdiDriven Trends through R\&D Policy?," D. A. Dyker, Closing the East-West Productivity Gap: Foreign Direct Investment, Competitiveness and Public Policy. London: Imperial College Press, 2006.

Radosevic, Slavo and Auriol, Laudeline (1999). "Patterns of Restructuring in Research, Development and Innovation Activities in Central and Eastern European Countries: An Analysis Based on S\&T Indicators." Research Policy, 1999, 28(4), pp. 351-76.

Srholec, M. (2006) Global production systems and technological catching-up: thinking twice about high-tech industries in emerging countries, In Piech, K. and Radosevic, S. eds. Knowledge Based Economy in Central and Eastern Europe: Countries and Industries in a Process of Change. London: Palgrave, pp. 57-78

Van Ark, Bart (1999)"Economic Growth and Labour Productivity in Europe: Half a Century of East - West Comparisons." Groningen Growth and Development Centre, Research Memorandum, 1999, GD-14.

van Ark, Bart and Piatkowski, Marcin (2004). "Productivity, Innovation and Ict in Old and New Europe." International Economics and Economic Policy, 2004, 1(2-3), pp. 215-46.

Verspagen, B. (2001). "Economic Growth and Technological Change: An Evolutionary Interpretation." STI Working Papers 2001/1, OECD, Paris.

Dahlman, C.J., Ross-Larsonn, B. and Westphal, L. (1987), 'Managing Technological Development: Lessons from the Newly Industrializing Countries', World Development, 15 (6) 759_ 75.

Zukowski, Ryszard (1998). "From Transformational Crisis to Transformational Recovery: The Case of Poland's Industry." Economic Systems, 22(4), pp. 367-97. 